\title{
ACCESSORY SPLEEN: A CLINICALLY RELEVANT ANATOMIC ANOMALY
}

\author{
Prachi Saffar Aneja1 ${ }^{1}$ Amit Kumar Saxena², Ankur Sharma ${ }^{3}$ \\ ${ }^{1}$ Associate Professor, Department of Anatomy, Faculty of Medicine and Health Sciences, SGT University, Gurgaon. \\ ${ }^{2}$ Associate Professor, Department of Anatomy, Faculty of Medicine and Health Sciences, SGT University, Gurgaon. \\ ${ }^{3}$ Tutor, Department of Anatomy, Faculty of Medicine and Health Sciences, SGT University, Gurgaon.
}

\section{ABSTRACT}

The purpose of our study is to emphasize on the clinical relevance of the presence of accessory spleen. It is not only a welldocumented anatomic anomaly, it holds special significance in the differential diagnosis of intra-abdominal tumours and lymphadenopathy.

\section{MATERIALS AND METHODS}

Thirty male cadavers from North Indian population above the age of 60 yrs. were dissected in the Anatomy Department of FMHS, SGT University, Gurgaon, over a period of 5 yrs. (Sep 2010-Aug 2015) and presence of accessory spleen recorded. Tissue from the accessory spleen was also subjected to routine histological processing and slide prepared by haematoxylin and eosin staining.

\section{RESULTS}

Accessory spleen was present in two cadavers near the splenic hilum. One was $3.9 \mathrm{~cm}$ in the long axis and weighed about 48.4 grams, while the other was $1.2 \mathrm{~cm}$ in long axis and weighed about 12.5 grams. One had a separate arterial branch from the main splenic artery; that it was splenic tissue was confirmed histologically.

\section{DISCUSSION}

The presence of accessory spleen is considered to be due to embryonic non-fusion of the splenic aggregate with the main mass.

\section{CONCLUSION}

Though accessory spleen in itself pose no clinical problems, its significance cannot be undermined. Surgeons and radiologists are advised to look for and rule out the presence of accessory spleen, especially while evaluating a case of abdominal and perineal pathology, else it may be wrongly diagnosed as malignant tumour or enlarged lymph node leading to grave consequences.

\section{KEYWORDS}

Accessory Spleen, Clinical, Embryonic Development, Trauma.

HOW TO CITE THIS ARTICLE: Aneja PS, Saxena AK, Sharma A. Accessory spleen: a clinically relevant anatomic anomaly. J. Evolution Med. Dent. Sci. 2016;5(14):637-639, DOI: 10.14260/jemds/2016/146

\section{INTRODUCTION}

Accessory spleen is an anatomic variant observed time and again in cadaveric dissection. It is present in about $10 \%$ of the individuals.1,2 The most common site of an accessory spleen is the splenic hilum, but accessory spleens have also been found in various other parts of the body; for example in the wall of the jejunum, in the mesentery and even in the pelvis. 3,4

Though it is generally asymptomatic and hence an incidental finding, studies on the subject have gained particular attention. The most important reason being that it mimics certain pathologies and hence the differential diagnosis becomes clinically relevant not only for the radiologist, but also for the surgeons. The treatment modality can range from 'no treatment required' to major surgeries and thus it becomes imperative to diagnose an accessory spleen even if it is done only with an intention to rule out grave pathology.

Financial or Other, Competing Interest: None.

Submission 05-01-2016, Peer Review 30-01-2016,

Acceptance 05-02-2016, Published 17-02-2016.

Corresponding Author:

Dr. Prachi Saffar Aneja,

D-10/05, GF Ardee City, Sector 52,

Gurgaon-122011, Haryana, India.

E-mail:dr.prachi@yahoo.co.in

DOI: 10.14260/jemds/2016/146

\section{MATERIALS AND METHODS}

Thirty embalmed male cadaver of 60 yrs. or above from North Indian population were dissected in anatomy dissection hall, FMHS, SGT University, Gurgaon, over a period of 5 yrs. (Sep 2010-Aug 2015) and presence of accessory spleen recorded. Those cadavers in which accessory spleen was present were photographed. After photographic session, both normal and accessory spleens from the aforesaid cadavers were removed and dimensions including weight recorded. Pathologist took biopsy specimen from the normal and accessory spleen. Tissues were subjected to histological processing. Paraffin sections were cut and subjected to haematoxylin and eosin staining. Study was done under low power microscopy.

\section{RESULTS}

Out of the thirty cadavers dissected, accessory spleen was present in two cadavers. In cadaver-1, normal spleen was 11.7 $\mathrm{cm}$ in the long axis and weighed about 180.3 grams. In cadaver-2, the normal spleen was $12.1 \mathrm{~cm}$ in the long axis and weighed about 190.5 grams.

Accessory spleen - Accessory spleen was present in two cadavers near the splenic hilum. In cadaver-1, it was $3.9 \mathrm{~cm}$ in the long axis and weighed about 48.4 grams, while in cadaver2 the accessory spleen was $1.2 \mathrm{~cm}$ in long axis and weighed about 12.5 grams. One had a separate arterial branch from the main splenic artery. 
That they were splenic tissue was confirmed histologically by observing the slide under low power microscopy.

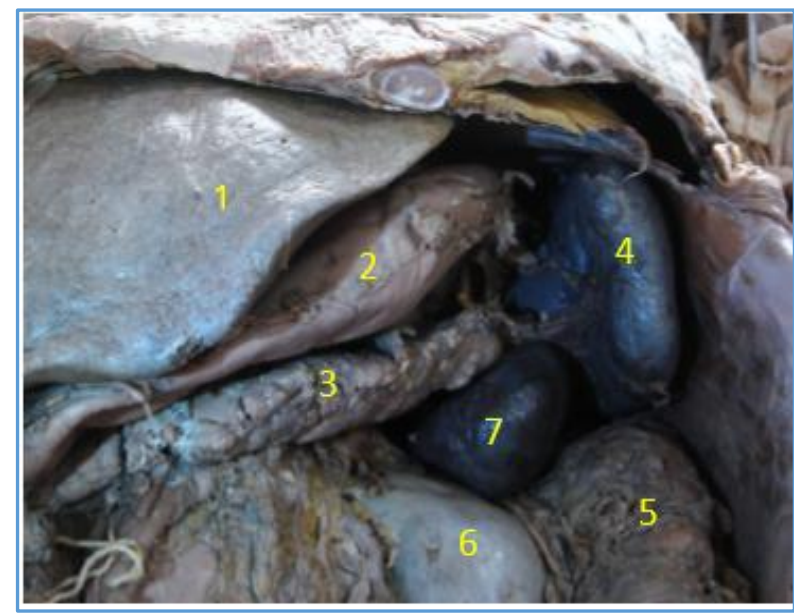

Fig. 1: Anterior View of Abdomen showing

1. Liver, 2. Stomach, 3. Pancreas,

4. Spleen, 5. Sigmoid Colon, 6. Kidney,

7. Accessory Spleen

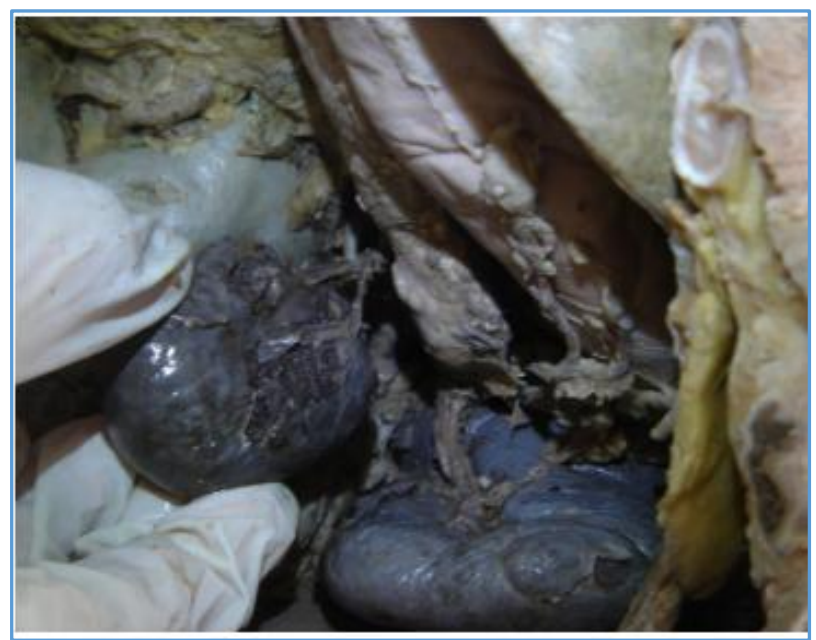

Fig. 2: Showing Accessory Spleen with its Accessory Spleen and Adjacent Structures, Arterial Supply

\section{DISCUSSION}

The presence of accessory spleen is well documented. Two totally unrelated theories are prevalent to advocate their presence. Beneke maintains that trauma with implantation and later regeneration of splenic particles is responsible for large number of accessory spleens. Majority of the authors, however, support the developmental theory as the most probable explanation. 5

The embryonic development of accessory spleens can be understood by taking into account the following five phases of splenic development: (1) The manner of formation of the major spleen with its notches and lobulations from separate splenic masses originating on the left side of the dorsal mesogastrium; (2) The formation of an accessory spleen by failure of fusion of splenic anlagen (Failure of fusion of the mesenchymal buds in the dorsal mesogastrium during the 5th week of fetal life). 6 ; (3) The formation and development of the subjacent dorsal mesogastrium into the various peritoneal ligaments and bursae carrying along the accessory spleens to their various distant locations.7; (4) The development of the splenic artery and its branches with similar distribution to both splenic lobules and accessory spleens.8; and (5) The embryonic contiguity of the splenic anlagen to the genital ridge, thus permitting an accessory spleen to become attached to the left gonad and to descend with it into the pelvis or scrotum. $9,10,11$

As stated earlier by Curtis and Movitz. ${ }^{12}$ the presence of a branch from one of the splenic artery terminals, which also supplies the major spleen lobule also strengthens the developmental theory for the presence of accessory spleen. Accessory spleen is thus considered as one of the aggregate mass intended to form part of the spleen and hence represents a greater degree of fusion-failure when compared to cleft and lobule formation. The presence of a branch of splenic artery supplying the accessory spleen in the present case is in accordance with the findings of earlier authors.

Many authors believe that there is a greater incidence of accessory spleen among the young, because these spleens undergo progressive involution and atrophy with advancing age. ${ }^{13}$ The onset of a pathologic process in splenic tissue apparently causes the accessory to remain functional and thus we find documents reporting increased frequency of accessories in those with certain splenic diseases. ${ }^{12}$

Accessory spleens are usually about $1 \mathrm{~cm}$ in diameter, but vary from microscopic deposits not visible on CT to $2 \mathrm{~cm}$ or $3 \mathrm{~cm}$ in diameter.1,2,14 It resembles a lymph node, both on CT and macroscopically. ${ }^{2}$ It is round or oval and its attenuation is identical to that of splenic tissue. ${ }^{15}$

As stated by Se Hyung Kim, MD. ${ }^{16}$ an accessory spleens usually pose no clinical problems and no treatment is necessary except in the following three circumstances: First an accessory spleen may mimic lymphadenopathy or tumours in other abdominal organs including the pancreas. Second, accessory spleen occasionally may become symptomatic because of torsion, spontaneous rupture, haemorrhage and cyst formation. Third, all functional splenic tissue should be removed for the treatment of haematologic disorders, such as Idiopathic Thrombocytopenic Purpura (ITP). An accessory spleen may be of clinical importance as a source of "preservable" splenic tissue in cases of a ruptured primary spleen. 15

\section{CONCLUSIONS}

Thus the author concludes on the note that though accessory spleen is well documented and in itself is not clinically relevant, its significance cannot be undermined. Its correct and accurate diagnosis holds immense significance in the clinical practice, especially for the surgeons and the radiologist. Such an anatomical variant can assume enormous importance if wrongly diagnosed as malignant tumour or enlarged lymph node. The physical and mental trauma a patient would have to endure if an accessory spleen is wrongly diagnosed is uncalled for. Surgeons and radiologist are thus advised to execute utmost caution while dealing with pathologies, which might resemble an accessory splenic tissue. Looking for and ruling out the presence of accessory spleen should thus become a part of all routine radiological procedures done to evaluate abdominal pathologies. 


\section{REFERENCES}

1. Moore KL, Persaud TVN. The digestive system. In: Moore KL, Persaud TVN, editors. In: The developing human, clinically oriented embryology ( $6^{\text {th }}$ edn). Philadelphia, PA: WB Saunders Co, 1998; pp 271-302.

2. Moore KL, Dalley AF. Abdomen. In: Moore KL, Dalley AF, editors. Clinically oriented anatomy (4th edn). Philadelphia, PA: Lippincott Williams \& Wilkins, 1999; pp 175-350.

3. Halpert B, Gyorkey F. Lesions observed in accessory spleens of 311 patients. Am J Clin Pathol, 1959;32: pp 165168.

4. Dodds WJ, Taylor AJ, Erickson SJ, et al. Radiological imaging of splenic anomalies. Am J Roentgenol 1990;155: pp 805-810.

5. Robert F, Robertson Montreal. The clinical importance of accessory spleens. Can Med Assoc J. 1938 September; 39(3): pp 222-225.

6. Grinbaum R, Zamir O, Fields S, et al. Torsion of an accessory spleen. Abdom Imaging 2006;31:110-112.

7. Mannie Stein MB, BCH (Rand). A case of ectopic spleen SA Tydskrif Vir December 1953; pp 1113.

8. Michels NA. Variational anatomy of spleen and splenic artery. Am Jr Anatomy, January, 194, 270, pp 21-72.
9. Sneath WA: an apparent third testicle consisting of a scrotal spleen. Jour Anat and Physiol, 1912-1913;47: pp 340-342.

10. Emmett JM and Dreyfuss ML: accessory spleen in scrotum. Annals of surgery, May 1943, 17, pp 754-759.

11. Olken HG: accessory splenic tissue within scrotum. Am Jr Path, January 1945;21: pp 81-85.

12. George M Curtis, MD; David Movitz,* MD. The surgical significance of the accessory spleen. Ann Surg 1946 February; 123(2): pp 276-298.

13. Witold J Rudowski, MD. Accessory spleens: clinical significance with particular reference to the recurrence of idiopathic thrombocytopenic purpura. World J of Surg, June 1985;9(3): pp 422-430.

14. Koehler RE. Spleen. In: Lee JKT, Sagel SS, Stanley RJ, editors. Computed body tomography with MRI correlation (2nd edn). New York: Raven Press, 1989; pp 521-41.

15. Gayer G, MD; Zissin R, MD; Apter S, MD, et al. Pictorial review - CT findings in congenital anomalies of the spleen. The British Journal of Radiology, 74 (2001), pp 767-772.

16. Se Hyung Kim, MD1; Jeong Min Lee, MD1,2; Joon Koo Han, $\mathrm{MD}^{1,2}$ et al. Intrapancreatic accessory spleen: findings on MR imaging, CT, US and scintigraphy and the pathologic analysis. Korean J Radiol 2008;9: pp 162-174. 